\title{
MICROBIOLOGICAL AIR QUALITY OF PROCESSING AREAS IN A DAIRY PLANT AS EVALUATED BY THE SEDIMENTATION TECHNIQUE AND A ONE-STAGE AIR SAMPLER
}

\author{
Valéria Costa Salustiano; Nélio José Andrade*; Sebastião César Cardoso Brandão; \\ Raquel Monteiro Cordeiro Azeredo; Sandra Aparecida Kitakawa Lima
}

Departamento de Tecnologia de Alimentos, Universidade Federal de Viçosa, Viçosa, MG, Brasil.

Submitted: July 10, 2002; Returned to Authors: October 10, 2002; Approved: June 26, 2003

\begin{abstract}
The microbiological air quality at processing areas in a dairy plant was evaluated by using a one-stage air sampler, based on Andersen principles (impaction technique) and by culture settling plate technique, also known as sedimentation technique. Among these areas, milk reception, packaging, and pasteurization rooms were included. Rooms where cheese, yogurt, butter and "doce de leite" (Latin American typical treat made of concentrated milk and sugar) are made were also evaluated. For all processing areas, the numbers of mesophilic aerobic bacteria and yeast and molds recovered by air sampler were higher than $90 \mathrm{CFU} \cdot \mathrm{m}^{-3}-$ the maximum value recommended by American Public Health Association (APHA). In four of the six processing areas, the microbial numbers were higher than APHA's standard $\left(30 \mathrm{CFU} . \mathrm{cm}^{-2}\right.$. week $\left.{ }^{-1}\right)$ according to culture settling plate technique. The results showed a difference $(\mathrm{p}<0.05)$ for the Staphylococcus aureus numbers (from $<1.0$ to $4.3 \mathrm{UFC} \cdot \mathrm{m}^{-3}$ ) at processing areas. The numbers of microorganisms recovered by impaction technique were about 2 to 10 times higher than by sedimentation technique. The microorganism group determined at processing areas depended mainly on the technique. By the air sampler technique, it was observed the predominance of yeasts and molds and by sedimentation technique, of mesophilic aerobic bacteria. The increase of temperature at processing areas did not seem to affect the numbers of airborne microorganisms. On the other hand, the increase of air humidity showed a relation with the increase of microorganism numbers. The impaction technique should be chosen since it is better to recover airborne microorganisms, including pathogens.
\end{abstract}

Key words: Dairy plant, air processing areas, microbiological quality, air sampler.

\section{INTRODUCTION}

During production the air of processing areas can contaminate foods with pathogenic or spoilage microorganisms, affecting their quality. Dairy products are particularly susceptible to contamination by airborne microorganisms'. The greatest aerosol sources in dairy plants are personnel, floor drains, ventilation system and water, when applied under pressure in the cleaning and sanitizing procedures $(1,6,15)$. Food contact processing surfaces can support growth of microorganisms and become a contamination source for the aerosols formation in the air processing areas (4).
Several techniques for microbiological air quality determination have been developed $(7,14)$. One of them is the air sampler technique, based on the number of microorganisms in a given air volume, suctioned by a sampler that allows the recovery of viable particles on a solid culture medium surface such as the plate count agar (7). An alternative procedure is the sedimentation technique as culture settling plates, based on deposition of viable particle on the surface of a solid culture medium per a given exposure time, as proposed by the American Public Health Association (APHA) (14).

APHA recommends the following standards for aerobic plate count in the air of food processing areas: 90 CFU.m ${ }^{-3}$, when

*Corresponding author. Mailing address: Departamento de Tecnologia de Alimentos, Universidade Federal de Viçosa. Campus Universitário. 36571-000, Viçosa, MG, Brasil. Tel.: (+5531) 3899-1855. Fax: (+5531) 3899-2208. E-mail: nandrade@ufv.br 
evaluated by the air sampler technique and 30 CFU.cm ${ }^{-2}$.week ${ }^{-1}$ when evaluated by the culture settling plate technique, using plate count agar as culture medium (14)

In this research, the microbiological quality of the air in different processing areas of a dairy plant was evaluated using a one-stage Andersen air sampler and the culture settling plate technique.

\section{MATERIALS AND METHODS}

The number of airborne microorganisms of milk processing areas of a dairy plant was evaluated by culture settling plate technique and impaction technique. The following areas were evaluated: milk reception, packaging and pasteurization; and cheese, yogurt, butter and "doce de leite" processing rooms. The numbers of aerobic plate count (mesophilic aerobic bacteria), yeast and molds, total coliform and Staphylococcus aureus were determined using, respectively, plate count agar (PCA), potato dextrose agar (PDA), VRB agar (VRB) and Baird Parker agar (BPA), according to methods proposed by APHA (14). The experiment was conducted with a threefold repetition for each microbiological determination. For each repetition, 48 samples were collected for each technique. The intervals between the samplings were two weeks..

For the culture settling plate technique, open Petri dishes containing $20 \mathrm{ml}$ of culture media (PCA, PDA, VRB or BPA) were distributed at the processing areas and exposed for about 15 to 30 minutes. The Petri dishes were closed and incubated at $35^{\circ} \mathrm{C} / 48 \mathrm{~h}$ for aerobic plate count, $25^{\circ} \mathrm{C} / 3-5 \mathrm{~d}$ for yeasts and molds, $37^{\circ} \mathrm{C} / 48 \mathrm{~h}$ for S.aureus and total coliform (14). Results were expressed as CFU.cm ${ }^{-2}$. week ${ }^{-1}$.

For the impaction technique, volumes of 100,500 or $1000 \mathrm{~L}$ of air were suctioned by an air sampler and impressed on solid medium surface contained on Petri dishes, according to APHA's recommendation (14). The air sampler's lid, firstly sterilized at $121^{\circ} \mathrm{C} /$ 15 minutes, was sanitized with $70 \%$ ethyl alcohol, before and after each sampling. After microbial determinations, the Petri dishes were incubated in the same conditions as the culture settling plate technique. The results were expressed as CFU.m ${ }^{-3}$ of air.
The numbers of CFU.m ${ }^{-3}$ determined by impaction technique were corrected, as recommended by the manufacturer of the sampler, using a table based on the formula: $\operatorname{Pr}=\mathrm{N}[1 / \mathrm{N}+1 / \mathrm{N}-1$ $+1 / \mathrm{N}-2+1 / \mathrm{N}-\mathrm{r}+1]$, where $\mathrm{Pr}=$ probable number of $\mathrm{CFU} /$ air volume; $\mathrm{N}=$ total number of lid pores $(400), \mathrm{r}=$ lid pores that have already been crossed by viable particles (8).

A descriptive analysis of the results was done to evaluate the influence of humidity and temperature of the processing areas on the microorganisms' numbers using a dry and wet bulbs psicrometer. Lilliefors and Cochran tests were used to evaluate the normality and uniformity of the results, respectively. The averages of the $\log _{10}$ of the numbers of microorganisms at processing areas recovered by both techniques were compared by Duncan test $(5 \%)$.

\section{RESULTS}

Tables 1 and 2 show the microbial numbers obtained by culture settling plate and air sampler techniques. For all the processing areas in the dairy plant, the numbers of mesophilic aerobic bacteria and yeasts and molds obtained by a one-stage air sampler were higher than 90 CFU. $\mathrm{m}^{-3}$ - the maximum value recommended by APHA for mesophilic aerobic bacteria. Both mesophilic aerobic bacteria and yeasts and molds were higher than APHA's standard (30 CFU.cm ${ }^{-2}$. week ${ }^{-1}$ ), according to culture settling plate technique, in four processing areas. The culture settling plate technique was not able to detect coliforms and $S$. aureus in the evaluated processing areas.

The microbiological numbers in the air of the processing areas obtained by air sampler were between 10 CFU.m ${ }^{-3}$ and 1310 CFU. $\mathrm{m}^{-3}$ (Tables 1 and 2). There were no significant differences $(\mathrm{p} \geq 0,05)$ for the numbers of mesophilic aerobic bacteria and yeasts and molds, among the evaluated processing areas at the dairy plant.

The numbers of total coliform and $S$. aureus were between $<1.0$ and 1.7 and $<1.0$ and 4.3 CFU. ${ }^{-3}$, respectively. There were significant differences $(\mathrm{p}<0,05)$ among processing areas for the numbers of $S$. aureus determined by impaction technique and analyzed by Duncan test (Table 3) among the different

Table 1. Count range, average, and standard deviations of the numbers of yeast and molds and mesophilic aerobic bacteria as determined by impaction technique, at processing areas in a dairy plant.

\begin{tabular}{cccccccc}
\hline \multirow{2}{*}{ Processing areas } & \multicolumn{2}{c}{ Yeast and Molds } & \multicolumn{2}{c}{ Mesophilic Aerobic Bacteria } & \multicolumn{2}{c}{ Total Coliform } \\
\cline { 2 - 7 } & $\begin{array}{c}\text { Count range } \\
\text { CFU.m }\end{array}$ & $\begin{array}{c}\mathrm{X} \pm \mathrm{s} \\
\text { CFU.m }\end{array}$ & $\begin{array}{c}\text { Count range } \\
\text { CFU.m }\end{array}$ & $\begin{array}{c}\mathrm{X} \pm \mathrm{s} \\
\text { UFC. }^{-3}\end{array}$ & $\begin{array}{c}\text { Count range } \\
\text { CFU.m }^{-3}\end{array}$ & $\begin{array}{c}\mathrm{X} \pm \mathrm{s} \\
\text { UFC. }^{-3}\end{array}$ \\
\hline Milk reception & $70-160$ & $111.1 \pm 6.9$ & $110-600$ & $313.3 \pm 6.6$ & 0.00 & 0.66 & $0.00-0.66$ \\
Milk pasteurization & $90-260$ & $176.7 \pm 49.8$ & $20-380$ & $161.1 \pm 98.0$ & 0.00 & 0.66 & $0.00-0.66$ \\
Butter and doce de leite & $60-1310$ & $410.0 \pm 490.8$ & $10-440$ & $135.6 \pm 119.3$ & 0.00 & 0.00 & $0.00-0.00$ \\
Cheese & $90-610$ & $342.2 \pm 39.1$ & $100-920$ & $381.1 \pm 289.8$ & 0.33 & 1.66 & $0.33-1.66$ \\
Yoghurt & $100-940$ & $294.4 \pm 238.3$ & $100-320$ & $212.2 \pm 47.6$ & 0.00 & 0.66 & $0.00-0.66$ \\
Milk packaging & $100-280$ & $184.4 \pm 38.6$ & $60-170$ & $100.0 \pm 47.6$ & 0.00 & 0.33 & $0.00-0.33$ \\
\hline
\end{tabular}


Table 2. Count range, average, and standard deviations of the numbers of yeast and molds and mesophilic aerobic bacteria as determined by culture settling plates technique, at processing areas in a dairy plant.

\begin{tabular}{|c|c|c|c|c|}
\hline \multirow[b]{2}{*}{ Processing areas } & \multicolumn{2}{|c|}{ Yeast and Molds } & \multicolumn{2}{|c|}{ Mesophilic Aerobic Bacteria } \\
\hline & $\begin{array}{c}\text { Count range } \\
\text { CFU.cm }{ }^{2} \text {.week }{ }^{-1}\end{array}$ & $\begin{array}{c}\mathrm{X} \pm \mathrm{s} \\
\text { CFU.cm }{ }^{-2} \text {.week }\end{array}$ & $\begin{array}{c}\text { Count range } \\
\text { CFU.cm }{ }^{-2} \text {.week }\end{array}$ & 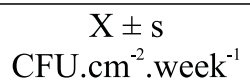 \\
\hline Milk reception & $10-42$ & $21.7 \pm 6.7$ & $11-89$ & $64.9 \pm 11.6$ \\
\hline Milk pasteurization & $21-52$ & $31.4 \pm 4.0$ & $10-73$ & $73.6 \pm 55.6$ \\
\hline Butter and doce de leite & $10-87$ & $39.6 \pm 28.0$ & $18-95$ & $46.9 \pm 53.6$ \\
\hline Cheese & $15-79$ & $45.2 \pm 5.4$ & $15-84$ & $37.6 \pm 8.3$ \\
\hline Yoghurt & $10-97$ & $45.5 \pm 30.2$ & $10-79$ & $54.0 \pm 58.5$ \\
\hline Milk Packaging & $13-42$ & $36.1 \pm 6.6$ & $10-50$ & $26.4 \pm 58.5$ \\
\hline
\end{tabular}

Table 3. Numbers of Staphylococcus aureus., as expressed $\mathrm{CFU} \cdot \mathrm{m}^{-3}$, at processing areas at a dairy plant. Averages of three repetitions.

\begin{tabular}{cc}
\hline Processing areas & Averages \\
\hline Milk pasteurized packaging & $3.00 \mathrm{a}$ \\
Cheese & $2.89 \mathrm{ab}$ \\
Butter and doce de leite & $1.11 \mathrm{abc}$ \\
Yogurt & $0.55 \mathrm{bc}$ \\
Milk pasteurization & $0.44 \mathrm{c}$ \\
Milk reception & $0.11 \mathrm{c}$ \\
\hline
\end{tabular}

Averages followed by the same letter in the same column did not differ among them, at $5 \%$ probability level, by Duncan Test.

processing areas at the dairy plant. These differences were not observed for total coliforms.

Fig. 1 shows the numbers of mesophilic aerobic bacteria in the air according to the temperature and humidity in the processing areas. Microbial counts were not affected by variations in the temperature. However, these counts had been influenced by air humidity.

\section{DISCUSSION}

\section{Microbiological air counts}

In addition to APHA, there are other recommendations for microbiological counts in the air at food processing areas. Kang and Frank, 1989, recommended 180-360 CFU.m ${ }^{-3}$ of air for mesophilic aerobic bacteria and 70-430 CFU. $\mathrm{m}^{-3}$ for yeasts and molds, according to food processing areas (5). Other researchers proposed limits at 200 CFU. $\mathrm{m}^{3}$ for dairy products' packaging rooms (10). In our study, the values recommended by APHA were adopted.

In our experiment, the microbial numbers between 10 and 1310 CFU. $\mathrm{m}^{-3}$ found in the air of the processing areas are similar to the results reported for other dairy processing areas, such as an ice-cream plant and processing and packaging room at a dairy

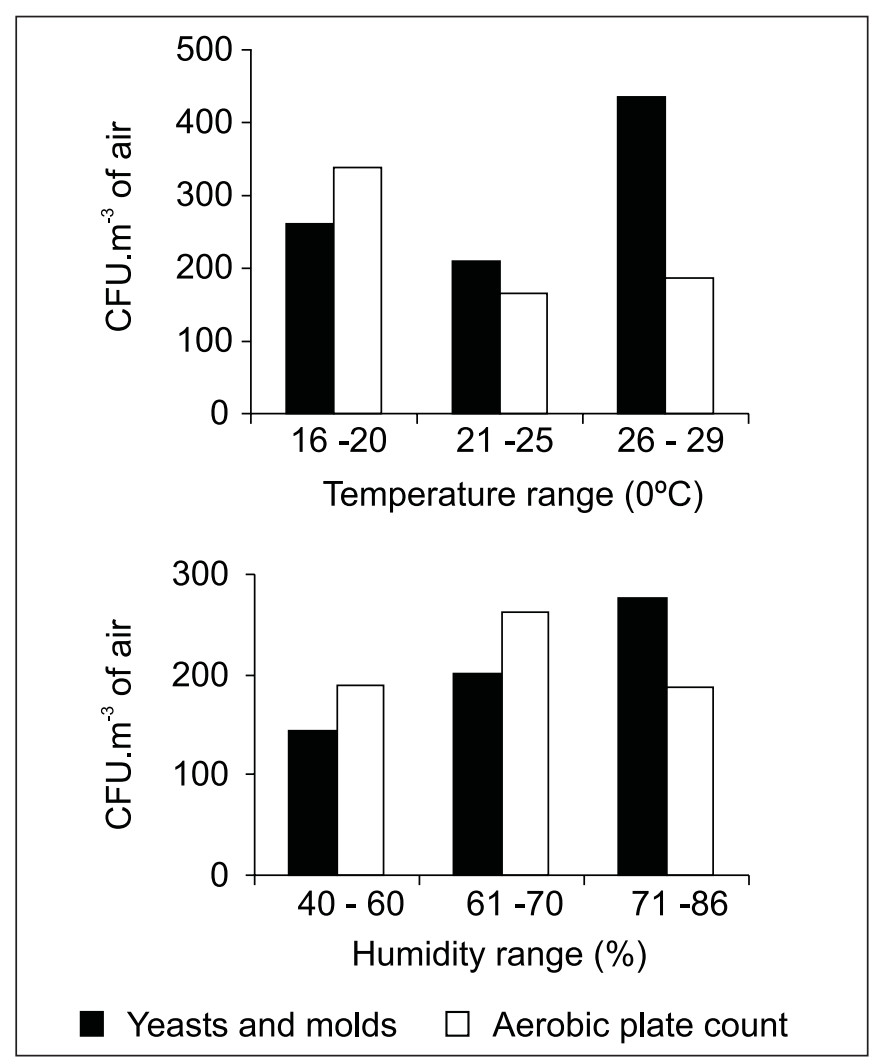

Figure 1. Influence of the temperature and humidity at processing areas in the number of yeast and molds and mesophilic aerobic bacteria, as determined by impaction technique.

plant $(9,10,11,13)$. Some of these experiments were conducted with the plant working, including personnel activity, similarly to our research. In our experiment, there were 3 to 5 manipulators in the processing area and they were probably responsible for the increased air contamination. It is known that one manipulator is able to spread between 20 and 70 microorganisms per min (3).

According to the literature, several factors could be contributing to air contamination at processing areas at the 
dairy plant evaluated in our experiment. Among them are: dairy plant localization, contamination sources, ventilation system, and manufacturing practices $(3,4)$.

The total coliform and $S$. aureus counts were between $<1.0$ and 3.0 and $<1.0$ and $1.7 \mathrm{CFU} . \mathrm{m}^{3}$, respectively. These numbers are lower than those obtained by Sullivan, 1979 (13), between 10 and 100 UFC. $\mathrm{m}^{-3}$. Such low numbers for coliform and S. aureus at processing areas suggest that these microorganisms do not survive well in aerosols. Furthermore, there is another possible explanation for these low numbers the microorganism growth could be affected by the use of selective media since they would be stressed in the aerosols $(2,14)$.

There are evidences in literature that the temperature affects the microbial number in the air. However, in our experiment, this was not observed for the microbial groups evaluated. This fact was probably due to environmental variations at the processing areas in a same working day and the presence of steam in air. The influence of temperature in the viability and in the vegetative cell transport in the air has been demonstrated (4).

The microbial groups detected at different processing areas varied according to the technique used to analyze the air. Four processing areas showed higher number of yeasts and molds when analyzed by impaction technique. Five processing areas presented higher numbers of mesophilic aerobic bacteria when the culture settling plate technique was used.

This fact could be explained by aerodynamic behavior of the aerosols, affecting the deposition of yeasts and molds on solid media surface exposed at air. The aerodynamic behavior of theses aerosols is different for each microbial group and is influenced by their physical and biological characteristics, diameter of the particle, humidity, temperature, ventilation and personnel activity at processing areas, gravitational and electrostatics forces (5).

\section{Impaction technique versus culture setting plate technique}

To compare the impaction and the culture settling plate techniques, a numeric relationship between APHA's standards was established (14). For that, the value of 30 (CFU.m ${ }^{-2}$. week ${ }^{-1}$ ) was divided by $90\left(\right.$ CFU.m $\left.{ }^{-3}\right)$ obtaining the numeric relation of 1:3. The Table 4 presents the numeric relation between the microbial counts obtained in our experiment by the different techniques. The impaction technique showed microbial numbers 2 to 10 times higher than those determined by the culture settling plates technique. On basis in these results, it can be concluded that impaction technique is better to recover higher number of microorganisms in air.

This lower capacity of the culture settling plate technique to recover microorganisms in the air is explained by the need of deposition of viable particles on the solid medium surface. For example, particles with diameter equal or higher than $10 \mathrm{~mm}$ are able to move vertically between 30 and $60 \mathrm{~cm}$ per minute while particles of lower diameter take longer to move the same distance
Table 4. Average and numeric relation between numbers of yeast and molds and aerobic plate countas determined by culture settling plates and impaction techniques at processing areas in a dairy plant.

\begin{tabular}{|c|c|c|c|c|c|c|c|}
\hline 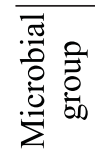 & & MPA & MR & BDL & $\mathrm{C}$ & $\mathrm{Y}$ & MI \\
\hline \multirow{3}{*}{ 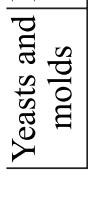 } & Impaction & 111.1 & 176.7 & 410 & 342.2 & 294.4 & 184. \\
\hline & Sedime & 21.7 & 31.4 & 39.6 & 45.2 & 45.5 & 36.1 \\
\hline & & $1: 5$ & 5 & $1: 10$ & $1 \cdot 7$ & $1: 6$ & $1: 5$ \\
\hline \multirow{3}{*}{ 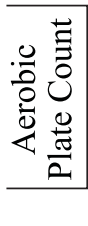 } & & 313.3 & 161.1 & 135.6 & 381.1 & 212.2 & 100 \\
\hline & $\mathrm{S}$ & 6 & 73.6 & 9 & 7.6 & 54.0 & 26 \\
\hline & Relation & $1: 5$ & $1: 2$ & $1: 3$ & $1: 10$ & $1: 4$ & $1: 4$ \\
\hline
\end{tabular}

$\mathrm{MPA}=$ milk pasteurization room; $\mathrm{MR}=$ milk reception room; $\mathrm{BDL}$ $=$ Butter and "doce de leite" room; $\mathrm{C}=$ Cheese room; $\mathrm{Y}=$ Yogurt room; $\mathrm{MP}=$ milk packaging room.

if there are no interferences from other factors, such as ventilation and personnel activity at processing areas (13). Similarly, the spore dimensions influence the deposition on surfaces. Molds were classified in three categories according to their dimensions: higher dimension spores (Alternaria, Stemphilium, Epicoccum, Nigrospora, Diplospora, Monotospora and Sepedonium); intermediate dimension spores (Geotrichum, Cândida, Pullularia, Saccharomyces, Aspergillus, Hormodendrum, e Penicillium) and lower dimension spores (Ustilago, Rhodotorula, Rhizopus, Oospora, Gliocladium, Paecilomyces, Hemispora, e Streptocyces). Once analyzed by culture settling plates and impaction techniques, the numeric relation found for spores with higher, intermediate and lower dimensions were approximately 1:5, 1:14 and 1:19, respectively (12). Furthermore, the lower the spore dimension, the more visible the difference between the techniques and the better the performance of the impaction technique.

Using culture-settling plates, most of the analysis showed neither total coliform, nor $S$. aureus growth on media culture surface. According to this method, this result expresses $<10$ $\mathrm{CFU} \cdot \mathrm{cm}^{-2} \cdot$ week $^{-1}$. It can be concluded that the impaction technique is better to determine low numbers of microorganisms at air food processing areas, including pathogens.

Also, the analysis time is an important factor to compare the techniques. The procedures of the culture settling plates suggest 15-30 min of air exposure time for the microorganism deposition. This relatively long exposure time can dry the media surface, dificulting the colonies growth and underestimating the microbial counts (5). In the procedures of impaction agar, the air suctioned 
is considered dried but, inside the sampler, the air humidity increases quickly, not causing the media surface to dry (1).

Regarding the air microbial contamination, it can be observed that none of the areas evaluated by impaction technique at the dairy plant complied with the APHA's standards. In addition, by the culture settling plates, the milk pasteurization room met APHA's recommendation for yeast and molds and the milk packaging room for mesophilic aerobic bacteria. Analyzed by culture settling plates, two processing areas $(33.4 \%)$ were approved for food processing due to this technique's lower capacity of recovering airborne microorganisms.

In spite of the higher initial cost of the impaction technique, due to the air sampler, this technique is faster and recovers more airborne microorganisms, being more sensitive to determine the pathogenic contamination at processing areas. In addition, the culture settling plate is currently classified by APHA as method D, which used to be considered standard but, due to technological advances, has been replaced by better methods. On the other hand, the impaction technique is classified as method B, since it was tested and used successfully in a higher number of researches and mainly under industrial conditions. The better quality of the data obtained by impaction technique justifies the high initial investment on the acquisition of an air sampler, particularly by industries that have a high technological level.

\section{ACKNOWLEDGEMENTS}

The authors would like to thanks to the CNPq and FAPEMIG for their financial supports to this research.

\section{RESUMO}

\section{Qualidade microbiológica do ar de ambientes de processamento em indústria de laticínios avaliada por amostrador de ar de um estágio e pela técnica da sedimentação}

Foi avaliada a microbiota do ar dos ambientes de recepção, embalagem e pasteurização de leite, produção de queijos, de iogurte e de doce de leite e manteiga em uma indústria de laticínios pelas técnicas de sedimentação e de impressão em ágar utilizando um amostrador de ar de um estágio baseado no princípio de Andersen. As contagens de microrganismos mesófilos aeróbios e de fungos filamentosos e leveduras pela técnica impressão em ágar ultrapassaram 90UFC $\cdot \mathrm{m}^{-3} \mathrm{de}$ ar, valor máximo recomendado pela APHA. Pela técnica de sedimentação, as contagens microbianas do ar de quatro ambientes também ultrapassaram 30UFC $\cdot \mathrm{cm}^{-2} \cdot$ semana $^{-1}$, conforme recomendação da APHA. Os ambientes diferiram $(\mathrm{p}<0,05)$ apenas para os números de Staphylococcus aureus. ( $<1,0$ a 4,3 UFC.m $\left.{ }^{-3}\right)$. As contagens microbianas por impressão em ágar foram de 2 a 10 vezes maiores que as obtidas por sedimentação, evidenciando a maior capacidade da impressão em ágar em determinar microrganismos do ar, inclusive patógenos. Quanto à distribuição da microbiota do ar, houve a predominância de fungos filamentosos e leveduras pela técnica de sedimentação em ágar e de mesófilos aeróbios pela de impressão em ágar. O aumento da temperatura ambiente, ao contrário do aumento da umidade relativa do ar, não contribuiu para maiores contagens microbianas no ar.

Palavras-chave: Indústria de laticínios, ar de ambientes de processamento, qualidade microbiológica, amostrador de ar.

\section{REFERENCES}

1. Andersen, A.A. New Sampler for the collection, sizing, and enumeration of viable airborne particles. J Bacteriol., 76: 471-484, 1958

2. Hicley, P.J.; Beckelheimer, C.E.; Parrow, T. Microbiological tests for equipment, containers, water, and air. In: Marshal, T. (ed) Standard Methods for the examination of Dairy Products. $16^{\text {th }}$ APHA, chapter 13, 1992, p. 397-412.

3. Heldman D.R. Significance and control of airborne contamination in milk and food plants. J. Milk and Food Technol., Alban, N.Y, 30:13-17, 1967.

4. Heldman, D.R. Factors influencing air-borne contamination of foods: A Review. J. Food Sci., 39:962-969, 1974.

5. Kang, Y.J.; Frank, F.J. Biological aerosols: A review of airborne contamination and its measurement in dairy processing plants. $J$. Food Protect., 52:512-524, 1989.

6. Kang, Y.J.; Frank, F.J. Characteristics of biological aerosols in dairy processing plants. J. Dairy Sci., 73:621-626, 1990.

7. Macher, M.J. Air sampling methods for biological contaminants Net. U.S.A., 2000. Disponível em: http://anderseninstruments.com/ Macher.htm

8. Merck. Microbial air Monitoring- MAS 100 Air Sampler: Technical Information. Net. Taiwan, 2001. Disponível em: http://www.merck.com.tw/.

9. Ren, T.J.; Frank, F.J. A survey of four fluid milk processing plants for airborne contamination using various sampling methods. J. Food Protect., 55:38-42, 1992a.

10. Ren, T.J.; Frank, F.J. Measurement of airborne contamination in two commercial ice cream plants. J. Food Protect., 55:43-47, 1992 b.

11. Ren, T.J.; Frank, F.J. Sampling of microbial aerosols at various locations in fluid milk and ice cream plants. J. Food Protect., 55:279283, 1992c.

12. Sayer, W.J.; Shean, D.B.; Ghosseiri, B.S. Estimation of airborne fungal by the Andersen sampler versus the gravity settling culture plate. J. Allergy, 15:214-227, 1969.

13. Sullivan. J.J. Air microbiology and dairy processing. Aust. J. Dairy Technol., 34:133-138, 1979.

14. Sveum. W.H.; Moberg, L.J.; Rude, R.; Frank, J.F. Microbiological monitoring of the food processing environment. In: Vanderzant, C.; Splittstoeser, D.F. (eds). Compendium of Methods for the Microbiological Examination of Foods. $3^{\text {rd }}$. APHA, Chapter. 3, 1992, p. 51-75.

15. Vickers, V.T. Control of airborne contamination in dairy processing plants. N. Zeal. J. Dairy Sci. Technol., 21:89-98, 1986. 